\title{
HUBUNGAN DISIPLIN DAN MOTIVASI TERHADAP HASIL LATIHAN BELADIRI KARATE PADA ANAK USIA 7-9 TAHUN DOJ O KKA (KARATE KID'S ACADEMY) DEPOK
}

\author{
Rista Mart Dwi Utanti \\ Tirto Apriyanto dan Firmansyah Dlis
}

\begin{abstract}
Abstrak. Penelitian ini bertujuan untuk mengetahui, (1) Hubungan disiplin dengan hasil latihan beladiri karate, (2) Hubungan motivasi dengan hasil latihan beladiri karate, (3) Hubungan secara bersama antara disiplin dan motivasi dengan hasil latihan beladiri karate.

Pengambilan data dilaksanakan di Dojo KKA (Karate Kid's Academy) Jln. Bango Balay Rakyat Depok 2 pada tanggal1 Juli 2015. Metode Penelitian yang digunakan dalam penelitian ini adalah deskriptif dengan teknik studi korelasi. Uuntuk memperoleh data pada variabel disiplin dan motivasi dengan menggunakan koesioner kumpulkan dengan wawancara langsung dengan responden, sedangkan untuk memperoleh data hasil latihan ditentukan atau kumpulkan dengan menghitung hasil perolehan skor anak saat melakukan tendangan.

Berdasarkan hasil penelitian, maka dapat dikemukakan bahwa latihan beladiri karate ditentukan oleh dua factor, diantaranya adalah disiplin dan motivasi, kedua komponen tersebut perlu dikembangkan secara optimal untuk mencapai penampilan yang optimal. Hasil penelitian (1) Disiplin (X1) memiliki hubungan yang signifikan dengan hasil latihan beladiri karate (Y) dengan koefisien sebesar 0,577 dan memberikan kontribusi sebesar 33,31\% terhadap hasil latihan beladiri karate. (2) Motivasi (X2) memberikan kontribusi sebesar 45,38\% terhadap hasil latihan beladiri karate. (3) Hasil latihan beladiri karate (Y) ditentukan atau dijelaskan oleh disiplin dan motivasi secara bersama-sama dengan hasil 68,0\%.
\end{abstract}

\section{Kata Kunci : Disiplin, Motivasi, Beladiri, Karate, Anak Usia 7-9 tahun}

\section{PENDAHULUAN}

\begin{tabular}{ccc} 
Dalam & kehidupan & \multicolumn{2}{c}{ sehari-hari } \\
seorang ibu setiap pagi selalu
\end{tabular} membangunkan ankanya untuk mandi dan pergi ke sekolah, akan tetapi kebiasaan anak yang selalu susah untuk dibangunkan dan susah untuk disuruh mandi merupakan salah satu ketidak disiplinan orang tua dalam mengajarkan kepada anaknya untuk membiasakan bangun pagi dan segera mandi untuk pergi sekolah. Setiap orang tua tidak akan pernah menginginkan anaknya tumbuh dengan tidak mempunyai kedisiplinan. Kenyataannyalah orang tua yang tidak menyiapkan anaknya untuk membiasakan menjadi anak seorang yang disiplin.

Ada kalanya orang tua harus mempunyai keteraturan dalam menerapkan kesepakatan atau aturan. Contoh, saat anak tidak mau mandi, dan orang tua tidak memarahi anaknya, sedangkan dilain waktu ketika anak tidak mau mandi orang tua lalu memarahinya. Ketidak teraturan itu yang membuat anak menjadi tidak disiplin, walaupun begitu setiap orang tua tidak menginginkan anaknya menjadi tidak disiplin.

Terkadang anak menjadikan dirinya menjadi disiplin ketika anak mengikuti kegiatan lain diluar rumah dan sekolah. Selain orang tua dan pendidik disekolah yang sering kali memberikan bimbingan dan pengajaran untuk menjadi pandai dan disiplin, anak membutuhkan kegiatan lain yang sifatnya sebagai hiburan dan menyehatkan serta berkaitan erat dengan pembelajaran terhadap kedisiplinannya. Dengan berolahraga, itu salah satu cara untuk membuat anak menjadi bugar dan sehat selain untuk hiburan dari kesibukan didalam sekolah. Olahraga merupakan suatu kegiatan aktifitas fisik yang tujuannya untuk kebugaran tubuh secara jasmani dan dapat mengatur metabolism dalam tubuh.

Karate adalah sebuah teknik yang memberikan keleluasaan pada setiap orang 
yang menggunakan kepalan tinju atau mempertahankan diri dengan tangan kosong. Karate merupakan cabang olahraga beladiri yang sudah dikenal lama di Indonesia dan merupakan cabang olahraga yang cukup digemari oleh masyarakat pada umumnya, baik dikotakota besar maupun di daerah kecil. Dengan mengikuti olahraga beladiri karate, anak bukan hanya menjadi bugar dan sehat tetapi anak juga dapat belajar menjadi lebih disiplin dan berani dalam melakukan sesuatu yang telah diperintahka oleh pelatihnya. Olahraga beladiri karate mampu mengembangkan motorik dan daya tangkap anak dengan seiring berlatihnya anak menghafal gerakan- gerakan yang diberikan oleh pelatihnya.

Anak dituntut untuk bias tepat waktu dalam mengikuti latihan, menaati semua peraturan yang telah diberikan oleh pelatihnya dan mengikuti pelatihan dengan baik dan tertib. Itu semua untuk membiasakan anak bersikap disiplin dan dapat bertanggung jawab dengan apa yang telah dilakukannya.

\section{KERANGKA TEORI DISIPLIN}

Disiplin adalah upaya mengendalikan diri dan sikap mental individu atau masyarakat dalam mengembakan kepatuhan dan ketaatan terhadap peraturan dan tatatertib berdasarkan dorongan dan kesadaran yang muncul dari dalam hatinya.

Disiplin merupakan proses bimbingan yang bertujuan menanamkan pola perrilaku tertentu, kebiasaan-kebiasaan tertentu atau membentuk manusia dengn ciri-ciri tertentu. Terutama, yang mengikuti kualiatas mental dan moral. Menurut Pratt, orang memiliki disiplin diri adalah mereka yang mampu mengarahkan tingkah lakunya sendiri sesuai dengan kebutuhan serta norma-norma (patokan tingkah laku) yang diterimanya.

Jadi inti dari disiplin ialah membiasakan anak untuk melakukan halhal yang sesuai dengan aturan yang ada disekitar lingkungannya. Disiplin dapat mencakup pengajaran, bimbingan atau dorongan yang dilakukan orang tua kepada anaknya. Menerapkan disiplin kepada anak bertujuan agar anak belajar sebagai makhluk social dan membiasakan diri untuk dapat berperilaku dengan lebih baik lagi, sekaligus agar anak mencapai pertumbuhan dan perkembangan yang optimal.

Disiplin berasal dari akar kata "disciple" yang berarti belajar. Disiplin merupakan arahan untuk melatih dan membentuk seseorang melakukan sesuatu menjadi lebih baik. Disiplin adalah suatu proses yang dapat menumbuhkan dan meningkatkan tujuan organisasi secara obyektif, melalui kepatuhannya dalam menjalankan peraturan.

Tujuan awal dari disiplin ialah membuat anak terlatih dan terkontrol. Untuk mencapai itu, orang tua dan pengajar harus mengajarkan kepada anak bentuk tingkahlaku yang pantas dan tidak pantas atau yang masih asing bagi anak dan sampai pada akhirnya anak mampu mengendalikan dirinya sendiri.Cara yang paling baik mendisiplinkan anak ialah dengan menggunakan pendekatan yang positif. Misal, memberikan teladan, dorongan, berkomunikasi dengan baik, memberi pujian dan hadiah. Sedangkan cara negative untuk mendisiplinkan anak antara lain memarahi, memukul atau membuat anak marah hingga proses belajarnya kurang maksimal.

Harlock mengatakan agar disiplin mampu mendidik anak untuk dapat berperilaku sesuai dengan standar yang ditetapkan oleh kelompok social mereka, maka disiplin harus memiliki empat unsur pokok yaitu:

\section{a. Peraturan}

Peraturan adalah pola yang ditetapkan untuk tingkah laku, dimana pola tersebut ditetapkan oleh orang tua, guru dan teman bermain. Tujuannya untuk membekali anak terhadap tingkah lakunya. Anak kecil lebih banyak membutuhkan peraturan dari pada anak yang lebih besar, sebab menjelang remaja anak dianggap telah belajar apa yang diharapkan dari kelompok social mereka. Ada dua fungsi dalam peraturan, yaitu: 
yang disetujui anggota kelompok tersebut.

2. Peraturan juga mampu mengekang perilaku yang tidak diinginkan.

Agar peraturan dapat memenuhi dua fungsi tersebut, maka peraturan ini haruslah dapat dimengerti, di ingat dan mudah diterima oelh anak.

b. Hukuman

Hukuman berasal dari kata kerja latin, puniture yang berarti menjaatuhkan hukuman pada seseorang karena suatu kesalahan, perlawanan atau pelanggaran sbagai ganjaran atau pembalasan. Hukuman memiliki tiga fungsi penting dalam perkembangan moral anak, yaitu:

1. Menghalangi, hukuman dapat menghalangi pengulangan tindakan yang tidak diinginkan oleh masyarakat. Contohnya, bila anak ingin melakukan sesuatu yang dilarang oleh orang tuanya ia akan mengurungkan niatnya karena mengingat hukuman yang pernah diterimanya karena ia melakuakan hal tersebut dimasa lampau.

2. Mendidik, sebelum anak memahami konsep peraturan, mereka mempelajari manakah tindakan yang benar. Hal tersebut dapat dipelajari anak melalui hukuman. Jika merka akan belajar dari pengalaman ketika menerima hukuman, apa bila merka melakukan yang tidak benar maka mereka akan mendapatkan hukuman dan apabila meraka melakukan hal yang benar maka mereka tidak akan mendapatkan hukuman.

3. Motivasi, fungsi hukuman yang ketiga adalah untuk menghindari perilaku yang tidak diterima oleh masyarakat. Pengalamannya mengenai akibat-akibat tindakan yang salah dan mendapatkan hukuman akan diperlukan sebagai motivasi untuk menghindari kesalahan tersebut. Bila nak mampu mempertimbangkan dengan baik tindakan yang akan merka lakukan dan mengetaui akibatnya, maka merka dapat belajar memutuskan tindakan tersebut apakah pantas atau tidak untuk dilakukan. Dengan demikian mereka memiliki motivasi unuk menghindari tindakan yang tidak benar.

c. Penghargaan

Penghargaan berarti memberikan sebuah hadiah dalam suatu bentuk apresiasi atau hasil yang baik.Penghargaan tidak perlu berbentuk materi, tetapi dapat berupa kata-kata pujian, senyuman bangga, atau tepukan dipunggung. Penghargaan mempunyai beberapa peranan penting dalam mengajar anak untuk berperilaku sesuai dengan cara yang dipersetujui oleh masyarakat, yaitu:

1. Penghargaan mempunyai nilai didik.

2. Penghaargaan sebagai motivasi untuk mengulangi perilaku yang disetujui secara social.

Adapun bentuk penghargaan yang digunakan, penghargaan itu harus sesuai dengan perkembangan anak. Bila tidak, anak akan kehilangan efektivitasnya. Dengan meningkatnya usia penghargaan bertindak sebagai sumber motivasi yang kuat bagi anak untuk melanjutkan usahanya agar berperilaku baik dan sesuai dengan harapan.

d. Kosistensi

Konsistensi berarti tingkat beragam atau stabilitas. Peraturan, hukuman dan penghargaan yang konsisten membuat anak tidak bingung terhadap apa yang diharapkan dari mereka. Ada beberapa fungsi dari konsistensi, yaitu:

1. Mempunyai nilai didik.

2. Mempunyai nilai motivasi yang kuat.

3. Mempertinggi penghargaan terhadap peraturan dan orang yang berkuasa.5

Anak yang diberikan pendidikan disiplin yang konsisten cenderung lebih matang disiplin dirinya bila dibandingkan dengan anak yang tidak diajarkan kedisiplinan secara konsisten.

Dalam disiplin anak harus bias menaati atau menjalankan semua peraturanperaturan yang ada dilingkungannya, seperti dilingkungan sekolah, dilingkungan rumah, dan lain-lain. Ada beberapa contoh peraturan yang anak harus biasakan lakukan dan dijalankan dengan baik pada saat mengikuti kegiatan diluar sekolah 
(mengikuti kegiatan latihan beladiri karate), seperti; datang tepat pada waktunya, harus selalu memberikansalam kepada orang yang lebih tua, meletakkan barang-barang pribadi dengan rapih, melakukan do'a bersama sebelum dan sesudah melakukan kegiatan latihan, membereskan alat-alat yang digunakan selama mengikuti kegiatan latihan.

Selama mengikuti olahraga beladiri karate, anak diajarkan untuk membiasakan diri menjadi disiplin dan mandiri dan setelah mereka memahami mereka harus mematuhi semua perturan yang sudah ada agar anak bisa menjadi lebih disiplin dan terkontrol.

Jadi dapat disipulkan disiplin adalah proses bimbingan yang tertujuan untuk membentuk perilaku seseorang agar menjadi lebih baik lagi dan dapat mengarahkan tingkah lakunya sendiri sesuai dengan ketentuan dan norma- norma yang ada.

\section{MOTIVASI}

Sejak lahir menusia telah telah membawa motif-motif tertentu. Dengan motif itu individu berusaha memenuhi kebutuhan-kebutuhannya, terutama untuk kelangsungan hidupnya.Ini berarti motif yang alami (natural motives) yang telah ada pada waktu lahir. Dalam perkembangan selanjutnya individu memenuhi kebutuhankebutuhan itu yang manifestasinya dipengaruhi oleh keadaan lingkungan, dan karna itu ada motif-motif yang dipelajari.

Seseorang dikatakan memiliki motivasi tinggi dapat diartikan orang tersebut memiliki alasan yang sangat kuat untuk mencapai apa yang diinginkannya dengan mengerjakan pekerjaannya sekarang. Berbeda dengan motivasi dalam pengertian yang berkembang di kalangan masyarakat yang sering kali disamakan dengan semangat, seperti contoh dalam percakapan "saya ingin anak saya memiliki motivasi yang tinggi dalam belajar". Statemen ini bisa diartikan orang tua tersebut menginginkan anaknya memiliki semangat belajar yang tinggi.

Maka, perlu dipahami bahwa ada perbedaan penggunaan istilah motivasi di kalangan masyarakat. Ada yang mengartikan motivasi sebagai sebuah alasan, dan ada juga yang mengartikan motivasi sama dengan semangat.

Ada beberapa pengertian motivasi menurut para ahli, yaitu:

a. Menurut Mr. Donald, motivasi adalah suatu perubahan energi dalam diri (pribadi) seseorng yang ditandai dengan timbulnya perasaan dan reaksi untuk mencapai tujuan.

b. Menurut Usman, motivasi adalah suatu proses untuk menggiatkan motif-motif menjadi perbuatan atau tingkah laku untuk memenuhi kebutuhan dan mencapai tujuan atau keadaan dan kesiapan dalam diri individu yang mendorong tingkah lakunya untuk berbuat sesuat dalam mencapai tujuan.

c. Menurut Robbins dan Judge, mendefinisikan motivasi sebagai proses yang menjelaskan intensitas, arah dan ketekunan usaha untuk mencapai suatu tujuan.

Motivasi juga dapat diartikan sebagai dorongan (driving force) dimaksudkan sebagai desakan yang alami untuk memuaskan dan mempertahankan kehidupan.

Di samping itu ada beberapa kondisi dalam dunia olahraga yang dapat mempengaruhi motivasi seseorang seperti yang dikemukakan oleh Kumlesh sebagai berikut:

a. Sehat fisik dan mental.

b. Lingkungan sehat dan menyenangkan. c) Fasilitas dan alat memadai.

c. Jenis olahraga yang dilakukan sesuai dengan niat dan bakat.

d. Menariknya program latihan.

e. Menggunakan alat bantu audiovisual.

f. Metode mengajar atau melatih sesuai kebutuhan peserta didik.

Berdasarkan pendapat diatas dapat menunjukan bahwa motivasi setiap orang berbeda dalam melakukan aktivitas olahraga. Motivasi yang dilakukan adalah sebagai sumber penggerakdan pendorong yang bersifat dinamik.Sikap dan pendorong suatu tindakan terarah pada tujuan tertentu untuk mendapatkan kepuasan dan menghindari hal-hal yang tidak menyenangkan. 
Walaupun ada bermacam-macam pendapat mengenai motivasi namun teori kebutuhanlah yang banyak dibahas dan diterapkan dalam berbagai bidang seperti pendidikan, kepemimpinan, administrasi, dan ekonomi. Salah satu ahli psikologi yang merumuskan kebutuhan manusia adalah Abraham Maslow, dengan teori pemenuhan kebutuhan (satisfaction of need theory), Maslow membagi kebutuhan manusia pada lima tingkat :

1. Kebutuhan fisiologi,

2. Kebutuhan rasa aman,

3. Kebutuhan cinta kasih,

4. Kebutuhan penghargaan,

5. Kebutuhan aktualisasi diri.

Kebutuhan fisiologi

Kebutuhan fisiologi merupakan kebutuhan dasar, yang bersifat primer vital, yang menyangkut fungsi-fungsi biologis manusia untuk mempertahankan dan melangsungkan hidup.Contoh kebutuhan fisiologi yaitu makan, minum, tidur dan istirahat.

Kebutuhan rasa aman

Kebutuhan ini tampak pada perasaan keamanan atau keadaan psikis (kejiwaan) seseorang. Setiap orang akan merasa dirinya aman atau tidak bahaya bila keadaan suatu tempat ia berada dapat belajar menyesuaikan diri atau berinteraksi di lingkungan tersebut baik itu sarana dan prasarana maupun bergaul dengan masyarakat sekitar.

Kebutuhan cinta kasih

Kebutuhan ini berhubungan dengan orang lain, artinya orang lain dapat berfungsi sebagai sarana atau perantara untuk memberikan bantuan dan informasi dalam melaksanakan suatu tugas atau pekerjaan sebagai contoh bergaul denganteman atau bersosialisasi dengan orang lain pada suatu lingkungan tertentu.

Kebutuhan penghargaan

Setiap anak mempunyai kekurangan dan kelebihan, maka di dalam pertumbuhan dan perkembangannya ada yang bisa dikerjakan dan adapula yang tidak bisa dilakukan, oleh karena itu orang tua atau pelatih harus menyadari hal-hal demikian.

Kebutuhan aktualisasi diri.

Kebutuhan aktualisasi diri merupakan kebutuhan unutk mengembangkan semua bakat dan kemampuan seseorang.
Seseorang dapat dikatakan mampu mewujudkan dirinya jika ia dapat mengembangkan bakat dan kemampuan sebaik-baiknya. Didalam mengembangkan perwujutan diri itu perlu bantuan orang tua, guru atau pelatih.

Teori Maslow yang hirarkis tersebut bisa digunakan pada motivasi anak, karena urutan kebutuhannya yang dianggap cocok yaitu yang dimulai dari fisiologi hinggaaktualisasi diri. Hubungan motivasi anak mengikuti latihan beladiri karate dengan kelima kebutuhan manusia:

1. Hubungan motivasi anak dengan kebutuhan fisiologis

Kebutuhan ini bersifat biologis yang hubungannya dengan kesehatan jasmani dan rohani ada disetiap anak untuk mengikuti latihan karate agar dapat meningkatkan kedisiplinan kesehatan jasmani serta dapat meningkatkan kemampuan dalam berlatih.

2. Hubungan motivasi anak dengan kebutuhan rasa dan nyaman

Selama mengikuti latihan karate anak terasa aman dan nyaman karena semua anakmengikuti kegiatan latihan karate dengan senang hati dan tidak ada paksaan dari siapapun. Anakpun merasa aman karena diperhatikan dan diarahkan dengan baik oleh pelatihnya.

3. Hubungan motivasi anak dengan kebutuhan cinta kasih

Perhatian dan bimbingan yang diberikan pelatih pada anak murid membuat anak merasakan rasa cinta kasih sehingga anak bersemangat dalam melakukan semua perintah yang diberikan oleh pelatihnya. Anakpun selalu berusaha untuk melakukan yang lebih baik dalam berlatih agar dapat meningkatkan kemampuan dan memberikan rasa senang pada pelatihnya.

4. Hubungan motivasi anak dengan kebutuhan penghargaan

Pada umumnya orang lebih senang dipuji dan disanjung begitu pula dengan anakanak. Jika mereka memperoleh sebuah prestasi yang baik anak-anak akan senang mendapatkan pujian, sanjungan, dan bahkan penghargaan atas prestasi yang dia raih. Mereka akan lebih giat lagi dalam mencapai prestasi yang lebih tinggi untuk 
dapat memberikan kebanggaan dan penghargaan baik untuk diri sendiri, orang tua ataupun pelatih.

5. Hubungan motivasi anak dengan kebutuhan aktulisasi diri

Pada usia anak 7-9 tahun merupakan masamasa perkembangan dan pertumbuhan, untuk itu bagaimana seharusnya menjadikan seuatu kegiatan dan memperhatikan kegiatan aktualisasi diri anak bisa berkembang. Dengan memasukkan anak ke klub olahraga karate diharapkan anak dapat bekembang dengan baik dan positif sehingga anak mendapat prestasi dan mampu menguasai dirinya untuk bersikap disiplin. 11

Jadi kesimpulan dari motivasi adalah perubahan perilaku seseorang yang ditandai dengan timbulnya rasa atau reaksi untuk melakukan sesuatu yang ingin dilakukannya.

\section{LATIHAN}

Setiap orang harus meningkatkan kualitas dirinya, dalam hal ini adalah kualitas fisik yang harus dikembangkan secara terus menerus. Kualitas fisik seseorang dapat berkembang jika diiringi aktivitas. Aktivitas yang dimaksud adalah aktivitas yang menunjang terhadap perkembangan fisik orang tersebut, seperti olahraga.Latihan (dalam konteks olahraga) adalah aktivitas manusia yang menunjang terhadap pemenuhan kebutuhan fisiknya.

Pengertian latihan yang diutarakan oleh beberapa ahli:

1. Menurut Nossek, latihan adalah proses untuk pengembangan penampilan olahraga yang kompleks dengan memakai isi latihan, metode latihan, tindakan organisasional yang sesuai dengan tujuan.

2. Menurut Bompa, latihan adalah aktivitas olahraga yang sistematik dalam waktu yang lama, ditingkatkan secara progresif dan individual yang mengarah kepada ciri-ciri fungsi psikologis dan fisiologis manusia untuk mencapai sasaran yang titentukan.

3. Menurut Sukadiyanto, menerangkan bahwa pada prinsipnya latihan merupakan suatu proses perubahan kearah yang lebih baik, yaitu untuk meningkatkan kualitas fisik kemampuan fungsional peralatan tubuh dan kualitas psikis anak latih.

4. Menurut Harsono, bahwa latihan juga bisa dikatakan sebagai sesuatu proses berlatih yang sistematis yang dilakukan secara berulang-ulang yang kian hari jumlah beban latihannya kian bertambah.

Jadi dapat disimpulkan bahwa, latihan dalam bidang olahraga adalah untuk meningkatkan penampilan olahraga dalam melakukan aktivitas atau latihan harus sistematis. Sistematis yang dimaksud disini yaitu setiap aktivitas harus disesuaikan dengan kemampuan masing-masing orang, dari yang mudak ke yang sukar, dari yang sederhana ke yang rumit. Selain itu, harus tetap diingat bahwa ketika melaksanakan latihan kemampuan fisik,seseorang harus memperhatikan pengulangan dari setiap aktivitas yang dilakukan. Hal tersebut dilakukan untuk mencegah hal-hal yang tidak diinginkan seperti cedera otot, patah tulang, luka dan sebagainya.

Tujuan utama dari latihan (training) adalah untuk membantu atlet meningkatkan keterampilan dan prestasi olahraganya semaksimal mungkin.Adapun aspek-aspek latihan yang perlu dilatih secara seksama oleh atlet adalah latihan fisik, teknik, taktik dan mental. Keempat aspek tersebut saling memberikan pengaruh terhadap pencapaian suatu hasil, sehingga proses pelatihannya pun harus menyeluruh dan mencakup aspek-aspek tersebut. Batasan atau pengertian keempat aspek latihan tersebut adalah sebagai berikut:

a. Latihan fisik ditujukan untuk mengembangkan dan meningkatkan kondisi fisik secara keseluruhan, yang mencakup komponen- komponen fisik antara lain: kekuatan otot, kelentukan, kecepatan, koordinasi dan lain-lain.

b. Latihan teknik adalah latihan yang ditujukan untuk memahirkan (mempelajari dengan sungguhsungguh) teknik gerakan, seperti: teknik menendang bola, servis, lari cepat, lompat jauh, dan lain-lain. Latihan ini dimaksudkan untuk membentuk dan 
mengembangkan kebiasaan-kebiasaan motorik dan neuromuscular.

c. Latihan taktik adalah latihan yang ditujukan untuk menumbuhkan perkembangan dayatafsir pada atlet, tentang pola-pola permainan, strategi, teknik (rencana atau tindakan yang bersistem untuk mencapai tujuan) bertahan, teknik menyerang, sehingga lawan tidak berkutik atau hamper tidak mungkin regu lawan akan dapat mengacaukan regu kita dengan satu bentuk serangan atau pertahanan yang tidak kita kenal.

d. Latihan mental adalah hal yang menyangkut batin dan watak manusia.

Di dalam latihan mental lebih menekankan pada perkembangan emosional (bersifat cepat bertindak secara tiba-tiba menurut gerak hati), seperti percaya diri sportivitas, semangat bertanding, dan lainlain.

Jadi kesimpulan latihan adalah proses latihan yang sistematik dalam waktu yang lama, ditingkatkan secara progresif.

\section{KARATE}

Karate merupakan beladiri yang berkembang di Okinawa, lalu berasal dari Okinawa dan berkembang diseluruh Jepang. Karate adalah seni beladiri dari dua kata. Yaitu, karayang artinya tangan dan Te yang artinya kosong, jika disatukan menjadi karate maka artinya sebagai tangan kosong. Ditambah sufiks (akhiran) do berarti cara. Jadi, karate-do menerapkan cara hidup yang lebih dari sekedar mempertahankan diri.

Karate merupakan cabang beladiri tangankosong yang full body contack, semua anggota tubuh merupakan sasaran serang. Karate tidak hanya menggunakan tangan sebagai alat serang melainkan kaki juga bias menjadi alat serang yang didalam pertandingan bias mendapatkan nilai yang tinggi. Menurut Masutatsu Oyama, kata karate yang ditulis dengan huruf Jepang modern yang secara harfiahnya berarti tangan kosong, mempunyai pengertian sebagai berikut:

1. Karate adalah suatu alat untuk membela diri dengan tangan kosong atau tanpa senjata.
2. Karate juga diartikan jiwa yang kosong, bersih tanpa pikiran buruk atau pamrih, sehingga dengan jiwa yang bersih itu memungkinkan seseorang mempelajari dan memahami karate dengan benar.

Sebagai bapak karate dunia Gichin Funakoshi pertama kali memperkenalkan karate tradisional Okinawa di Tokyo Jepang. Dia sebagai pendiri dan penemu aliran Shotokan pada tahun 1938 yang mampu memposisikan karate dalam kehidupan budaya masyarakat Jepang hingga menyebar kepenjuru dunia. Karate sebelumnya bernama to te hanyya dan hanya diajarkan terbatas. Olahraga karate telah berkembang ke seluruh penjuru dunia, seiring berkembangnya olahraga, karate telah diminati banyak orang baik pelajar, mahasiswa, ataupun sebagai beladiri murni ataupun olahraga prestasi.

Pukulan dan tendangan sebagai suatu keterampilan yang harus dikuasai oleh para karateka dengan baik, sehingga latihan-latihan yang menunjang untuk dapat meningkatkan kemampuan pukulan dan tendangan diperlukan untuk menjaga konsistensi kemampuan para karateka itu sendiribaik dalam berlatih maupun pada saat bertanding.

Kepatuhan terhadap tradisi dan tata cara ini juga dimaksudkan sebagai sarana pendidikan kejiwaan dan kedisiplinan karateka. Adapun tata cara dan tradisi dalam karate:

1. Meditasi dan do'a

Latihan karate selalu diawali dan diakhri dengan melakukan meditasi. Meditasi ini dilakukan dengan sikap duduk timpuh dan mata terpejam. Kedua telapak tangan diletakan diatas paha, otot-otot dikendurkan, konsentrasi dipusatkan dan berdo'a untuk kekuatan dan keselamatan kepada Tuhan.

\section{Hormat karate}

Hormat karate dilakukan dengan sikap mula-mula berdiri tegap (sikap sempurna), kemudian badan dibungkukkan separuhnya.Hormat karate ini harus dilakukan dengan ikhlas dan penuh rasa persaudaraan.

3. Seragam karate

Lambing Faderasi Olahraga Karate-Do Indonesia (FORKI) harus dipasang pada 
baju karate (karategi) pada bagian dada sebelah kanan.

\section{Sistem sabuk}

Setiap karateka diharuskan untuk mengenakan sabuk atau ban.Akan tetapi sabuk tidak boleh dibuat sendiri atau diminta secara cuma-cuma kepada pelatih.Untuk memperoleh sabuk, karateka harus mengikuti serangkaian ujian kenaikan tingkat yang cukup berat.Sabuk merupakan tanda tingkatkan prestasi karate. Pada tingkat pemula karateka diberi dabuk putih dan jika sudah mengikuti ujian kenaikan sabuk akan merubah mendadi sabuk kuning, kemudian menjadi hijau, biru, coklat, dan terakhir hitam.

\section{Teriakan karate}

Setiap kali melakukan tendangan dan pukulan, karateka harus menyertai dengan teriakan.Teriakan yang biasa digunakan ialah "HUH" atau "UTS", dilakukan bersama-sama dengan hentakan napas.Teriakan karate (disebut KIAI) ini tidak dimaksudkan untuk merendahkan atau meremehkan lawan. Teriakan ini dimaksudkan untuk pemusatan energy dan sebagai cara untuk meneguhkan hati.

Dalam karate terdapat beberapa teknik yang harus dikuasai oleh anak yang mengikuti latihan karate, yaitu:

1. Teknik berdiri (dachi).

2. Teknik pukulan.

3. Teknik tendangan

4. Teknik tangkisan

5. Teknik dasar pertarungan (kumite).

6. Jurus (kata).

7. Peraturan pertandingan.

Ada beberapa teknik tendangan didalam karate Antara lain:

1. Maegeri

Tendangan lurus kedepan (maegeri) adalah tendangan yang dilakukan dengan arah lintasan dari belakang ke depan. Bagian kaki yang harus dibenturkan kea rah sasaran ialah ujung telapak kaki (koshi).Pada saat melakukan tendangan, jari-jari kaki ditekuk ke belakang atau menghadap ke atas. Sasaran utama dari tendangan ini ialah tubuh lawan bagian tengah;

dada, perut, dan alat kemaluan.

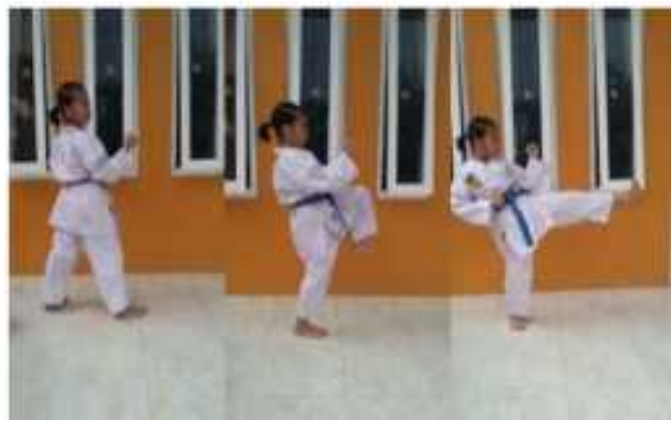

Gambar 1

Sikap awal, gerakan awal dan gerakan saat menendang.

2. Mawashi geri

Mawashi geri (tendangan melingkar) tendangan yang dilakukan gerakan kaki melingkar dari samping kanan atau kiri kea rah dalam.Bagian kaki yang digunakan untuk menendang ialah ujung kaki atau punggung kaki, namun pada keadaan-keadaan tertentu pedang kaki juga dapat digunakan sebagai alat serang dari tendangan ini.Kekuatan tendangan melingkar ini sangan didukung oleh putaran pinggul kaki yang digunakan sebagai tumpuan.

Pada dasarnya gerakan tubuh adalah merupakan senjata dalam karate seperti halnya yang diungkapkan oleh Masutatsu Oyama (1992:29) mengatakan bahwa "Kepala juga salah satu senjata yang jarang sekali digunakan dalam pertandingan resmi, kecuali untuk pembalasan diri yang betul-betul terdesak saja". Tangan dan kaki sangat memegang peranan dalam mencapai kemahiran dalam olehraga karate.

Tangan dan kaki ini sering digunakan dalam pertandingan, maka ke dua senjata ini harus memiliki gerak kuat dan cepat agar pukulan dan tendangan mengenai tepat pada sasaran. Lebih lanjut mengatakan bahwa "70\% dari semua teknik karate banyak menggunakan tendangan sebagai senjata yang cukup ampuh, oleh sebab itu seorang karateka harus memiliki tendangan yang benar-benar baik untuk dapat memperoleh angka kemenangan bila dalam pertandingan atau kumite".

Perhatikan cara melatihnya pada gerakan tendangan mawashi geri: 
a. Dimulai dengan sikap standar seperti pada waktu memulai tendangan- tendangan yang lainnya.

b. Angkat kaki kanan anda dan letakkan lutut sejajar dengan pinggang kanan. Persiapkan ujung telapak kaki kanan anda untuk menendang.

c. Kemudian tendangkan ujung telapak kaki yang telah anda angkat dengan gerakan ke samping kearah dalam. Pusatkan seluruh kekuatan pada ujung kaki, gunakan daya lenting lutut untuk mendukung pemusatan kekuatan tendangan ini. Jagalah keseimbangan badan anda agar tidak goyah atau jatuh.

d. Lakukan latihan tendangan melingkar tersebut berulang-ulang dan bergantian kiri dan kanan.

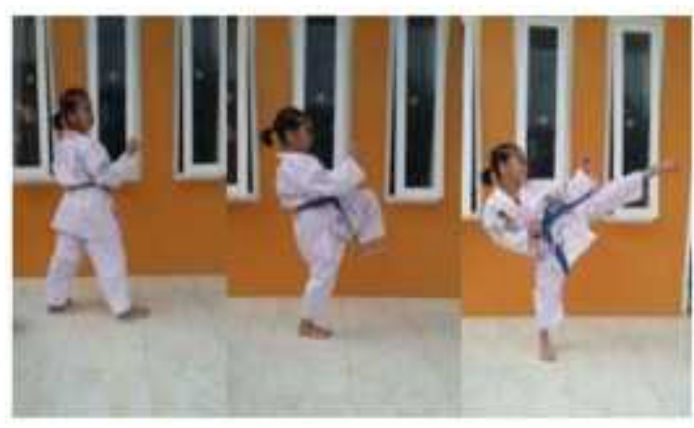

Gambar 2

Sikap awal, gerakan awal, dan gerakan saat menendang.

Jadi hakikat karate adalah seuatu olahraga keterampilan gerak beladiri yang memperagakan tangan kosong, dan dapat membentuk manusia untuk mengendalikan jiwa dan semangat bagi dirinya yang ditunjukan dalam kehidupan masyarakat.

\section{ANAK USIA 7-9 TAHUN}

Anak usia dini sedang dalam tahap pertumbuhan dan perkembangan baik fisik maupun mental yang paling pesat. Pertumbuhan dan perkembangan anak telah dimulai sejak prenatal, yaitu sejak dalam kandungan. Begitu pentingnya usia dini, sampai ada teori yang menyatakan bahwa "pada anak empat tahun 50\% kecerdasan telah tercapai, dan $80 \%$ pada usia delapan tahun".

Anak usia dini juga sedang mengalami pertumbuhan dan perkembangan baik fisik maupun mental yang sangat pesat. Sel-sel tubuh anak tumbuh dan berkembang amay cepat. Makannan bergizi dan seimbang serta stimulai pikiran sangat diperlukan untuk mendukung proses tersebut. Selain pertumbuhan dan perkembangan fisik dan motoric, perkembangan moral (termaksud kepribadian, watak, dan akhlak), social, emosional, intelektual dan Bahasa juga berlangsung amat pesat.

Anak usia 7-9 tahun adalah masa anak-anak pertengahan, selama masa anakanak pertengahan kecenderungan beraktifitas diteruskan tetapi dikendalikan termotivasi dengan adanya sebuah tujuan.

Anak-anak tetap ingin tahu dan mempunyai banyak pertanyaan yang harus dijawab dengan jujur tetapi alasnnya sekarang mulai berkembang dan anak-anak melukiskan kesimpulan dari penelitiannya dan pemikirannya sendiri. Hal-hal yang lama membawa arti-arti yang baru dan katakatanya tiap hari menjadi lebih banyak.

Karakteristik perkembangan anak pada kelas satu, dua dan tiga SD ataupun masa pertengahan biasanya pertumbuhan fisiknya telah mencapai kematangan, mereka telah mampu mengontrol tubuh dan keseimbangannya.30 Perkembangan anak usia pertengahan dari sisi emosi Antara lain anak telah dapat mengekspresikan reaksi terhadap orang lain,telah dapat mengontrol emosi, sudah mampu berpisah dari kedua orang tuanya dan telah mulai belajar tentang konsep nilai misalnya benar dan salah.

Anak usia pertengahan adalah individu yang sedang mengalami prose pertumbuhan dan perkembangan yang sangat pesat. Bahkan dikatakan sebagai lompatan perkembangan. Karna itulah maka usia ini dikatakan sebagai golden age (usia emas) yaitu usia yang sangat berharga disbanding usia-usia selanjutnya. Usia tersebut merupakan fase kehidupan yang unik.

Motivasi untuk mempelajari anakanak bukan berarti bahwa ia diabaikan, 
melainkan sebagaian terbesar penelitian awal bukan berasal dari minat terhadap anak itu sendiri atau terhadap perkembangannya tetapi terutaman dari minat terhadap cara mendidik mereka secara benar agar menjadi warga Negara yang berguna.33 John Amos Comenius berpendapat bahwa "anak-anak harus dipelajari bukan sebagai embrio orang dewasa melainkan dalam sosok alami anak yang penting untuk memahami kemampuan mereka dan mengetahui bagaimana berhubungan dengannya.

\section{KERANGKA BERPIKIR}

1. Hubungan antara Disiplin dengan Hasil Latihan Beladiri Karate.

Seorang anak kecil biasanya sangat menyukai bentuk-bentuk permainan dan hiburan. Olahraga beladiri karate membuat banyak manfaat bagi anak-anak dalam usia dini. Anak-anak sebagian besar sangat menyukai olehraga beladirikarate karena mereka senang dan nyaman dalam melakukan olahraga beladiri karate tersebut, keinginan untuk melakukan gerak dan ingin mengikuti gerakan-gerakan didalam karate membuat anak menjadi lebih senang dan sepenuh hati melakukannya bahkan mereka melupakan waktu untuk beristirahat dan terus menginginkan latihan tanpa henti.

Dengan mengikuti olahraga beladiri karate karakter anak dapat berkembang dan anak mempunyai kemampuan untuk berfikir dan bergerak dalam melakukan kegiatan yang sedang mereka gemari yaitu melakukan olahraga beladiri karate. Perkembangan psikologi anak setelah mengikuti olahraga beladiri karate anak menjadi lebih percaya diri, anak menjadi lebih terkontrol dalam mengendalikan sikap dan emosionalnya serta anak lebih mudah untuk diatur, dididik dan diarahkan dalam memberikan instruksi atau pengarahan dari orang tua, guru ataupun pelatihnya.

Anak lebih suka melakukan sesuatu yang lebih penting dibandingkan melakukan sesuatu hal yang sifatnya sia-sia atau percuma. Dapat membiasakan diri melakukan segala sesuatu yang telah ditetapkan atau yang berlaku didalam lingkungannya dan dapat mengontrol diri agar tidak melanggarnya.

2. Hubungan Motivasi dengan Hasil Latihan Beladiri Karate.

Rasa ingin melakukan yang lebih baik dan bersemangat dalam melakukan latihan merupakan bentuk motivasi anak untuk bias mendapatkan sebuah prestasi dan rasa bangga terhadap dirinya sindiri, orang tua maupun pelatihnya. Ia merasa lebih bersemangat ketika mendapat hukuman bila melakukan kesalahan dan berusah memperbaikinya serta tidak mengulagi kesalahannya lagi. Terkadang anak merasa bersemangat dalam latihan karena mendapat pelatih yang bijaksana, perhatian dan dapat membuat dia termotivasi dalam melakukan latihan dengan baik.

3. Hubungan Secara Bersama antara Disiplin dan Motivasi dengan Latihan Beladiri Karate.

Anak yang mengikuti olahraga beladiri karate rata-rata menjadi lebih suka melakukan kegiatan yang bersifatnya olehraga, permainan yang menjadi sebuah tantangan bagi mereka, supaya mereka mampu menguasai semua yang diberikan oleh pelatih atau orang yang memberikan ilmu atau pelajaran. Merekapun menjadi lebih berani dalam melakukan hal apapun yang sifatnya menantang ataupun yang standar.

Anak menjadi lebih kreatif dan rajin dalam melakukan sesuatu hal dalam kehidupan sehari-harinya. Tingkat kedisiplinan anak mulai berkembang setelah mereka mengikuti olahraga beladiri karate dan mendapat bimbingan dari pelatihnya dengan baik serta mempunyai motivasi untuk meningkatkan kemampuannya dalam menguasai gerakan-geerakan yang telah diajarkan oleh pelatih.

\section{METODE PENELITIAN}

Metode penelitian yang digunakan dalam penelitian ini adalah metode deskriptif dengan teknik studi korelasi, untuk memperoleh data pada variable disiplin dikumpulkan dengan cara menghitung hasil penilaian atlet yang dihitung oleh pelatih, kemudian untuk 
memperoleh data variable motivasi dikumpulkan dengan cara mengitung hasil angket yang dilakukan oleh pelatih, dua variable tersebut merupakan variable bebas. Sedangkan untuk memperoleh data hasil latihan dikumpulkan dengan cara menghitung hasil perolehan skor anak saat melakukan tendangan.

\section{HASIL PENELITIAN}

Hasil penelitian yang menyatakan bahwa: (1) Disiplin (X1) memiliki hubungan yang signifikan dengan hasil latihan beladiri karate (Y) dengan koefisien korelasi sebesar 0,577 dan memberikan kontribusi sebesar $33,31 \%$ tehadap hasil latihan beladiri karate. (2) Motivasi (X2) memiliki hubungan yang signifikan dengan hasil latihan beladiri karate $(\mathrm{Y})$ dengan koefisien korelasi sebesar 0,674. Motivasi (X2) memberikan kontribusi sebesar 45,38\% tehadap hasil latihan beladiri karate.

\section{Hasil latihan beladiri karate}

Data variabel hasil latihan beladiri karate diperoleh berdasarkan hasil tes yang terdiri atas 4 indikator yakni sikap awal, gerakan awal, saat menendang, dan gerakan akhir. Masing-masing dimensi diperoleh skor sebagai berikut:

Tabel 1 Perolehan Skor Data Berdasarkan Dimensi Variabel Y

\begin{tabular}{|c|c|c|c|c|c|c|c|}
\hline Nas. & $\begin{array}{l}\text { Dannowi Latilian } \\
\text { Belafint }\end{array}$ & Ne Bring & Butit & $\begin{array}{l}\text { Sarr } \\
\text { Total }\end{array}$ & $\begin{array}{c}\text { Kontang } \\
x\end{array}$ & Rents & $\begin{array}{l}\text { Penumen } \\
\text { nit }\end{array}$ \\
\hline \multirow{3}{*}{ t } & \multirow{3}{*}{ ILKUP AWAL. } & $I$ & 4 & \multirow{3}{*}{$2 \mathrm{H}$} & \multirow{3}{*}{4} & \multirow{3}{*}{$7 t, 2$} & \multirow{3}{*}{$26,13 * 6$} \\
\hline & & & a) & & & & \\
\hline & & $\frac{1}{4}$ & $\frac{67}{72}$ & & & & \\
\hline \multirow{3}{*}{2} & \multirow{3}{*}{$\begin{array}{l}\text { GERAKAN } \\
\text { AWAL }\end{array}$} & 2 & $\pi$ & \multirow{3}{*}{255} & \multirow{3}{*}{4} & \multirow{3}{*}{ is } & \multirow{3}{*}{28,501} \\
\hline & & $\frac{1}{7}$ & 32 & & & & \\
\hline & & $\frac{T}{1}$ & $\frac{65}{73}$ & & & & \\
\hline \multirow{3}{*}{3} & \multirow{3}{*}{$\begin{array}{l}\text { IUAT } \\
\text { SENENDLNO }\end{array}$} & 9 & e) & \multirow{3}{*}{292} & \multirow{3}{*}{4} & \multirow{3}{*}{6,0} & \multirow{3}{*}{$20,10 \leqslant$} \\
\hline & & 10 & 64 & & & & \\
\hline & & 11 & In & & & & \\
\hline \multirow{3}{*}{4} & \multirow{3}{*}{$\begin{array}{c}\text { GERAKAN } \\
\text { ACICR }\end{array}$} & $\frac{2}{11}$ & $\frac{9}{68}$ & \multirow{3}{*}{ set } & \multirow{3}{*}{4} & \multirow{3}{*}{ ons } & \multirow{3}{*}{20,4006} \\
\hline & & 19 & 65 & & & & \\
\hline & & $\frac{13}{10}$ & 71 & & & & \\
\hline & Imit: & & & $\mathrm{Men}$ & 16 & $27 y$ & 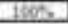 \\
\hline
\end{tabular}

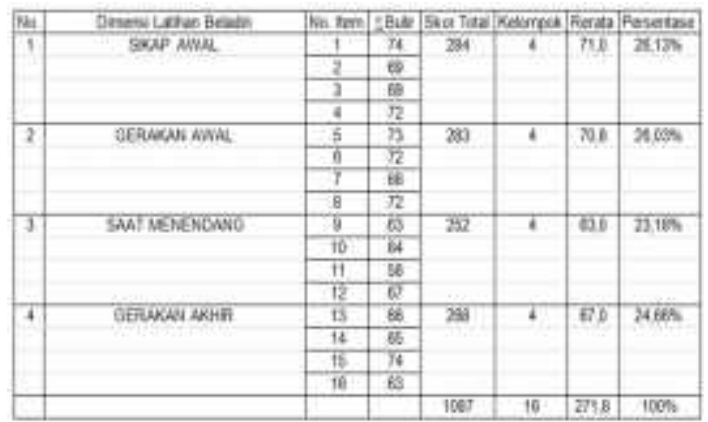

Berdasarkan tabel di atas diketahui bahwa skor rata-rata tertinggi hasil belajar beladiri karate diperoleh pada dimensi sikap awal dengan skor rata- rata 71,0 dan gerakan awal dengan skor rata-rata 70.8, gerakan akhir 67,0 dan saat menendang 63,0 .

Berdasarkan hasil analisis data diketahui skor minimum 50, skor maksimum 64 , rentang skor 14 , skor ratarata 57.21 , median 57 , modus 60 , standar deviasi 3,81, dan varians 14,51. Distribusi frekuensi skor hasil latihan bela diri karate dari 19 responden diperlihatkan dalam tabel berikut.

Tabel 2: Distribusi Frekuensi Skor Hasil latihan beladiri karate

\begin{tabular}{|c|c|c|c|c|}
\hline No. & Interval & Titik Tengah & Frekuens Absolut & FrehuensiRelabif \\
\hline 1 & $50-52$ & 51 & 2 & 10,5 \\
\hline 2 & $53-55$ & 54 & 4 & 21,1 \\
\hline 3 & $50-58$ & 57 & 6 & 31,6 \\
\hline 4 & $59-61$ & 60 & 4 & 21,1 \\
\hline 5 & $62-64$ & 63 & 3 & 15,8 \\
\hline & Total & & 19 & 100,00 \\
\hline
\end{tabular}

Data yang disajikan pada tabel di atas memperlihatkan sebaran skor hasil latihan beladiri karate yang terbagi dalam lima kelompok. Berdasarkan data pada tabel di atas, dapat digambarkan penyebaran skor hasil latihan beladiri karate dalam bentuk histogram frekuensi yang diperlihatkan pada gambar berikut.

\section{Disiplin}

Data variabel disiplin diperoleh berdasarkan hasil pengisian kuesioner yang terdiri atas 32 butir dengan rentang skor teoretis antara 32 sampai 160. Berdasarkan hasil analisis data diketahui skor minimum 91, skor maksimum 105, rentang skor 14, skor rata-rata 97.95, median 98, modus 99, standar deviasi 3,92, dan varians 15,39. Distribusi frekuensi skor disiplin dari 19 responden diperlihatkan dalam tabel berikut. 
Tabel 3: Distribusi Frekuensi Skor disiplin

\begin{tabular}{|c|c|c|c|c|}
\hline Ne & Intende & Tht Temant & Fengers Absodt & Frentersereatifi \\
\hline 1 & $91-9$ & 92 & 3 & 158 \\
\hline 2 & $94-86$ & 95 & 4 & $2 \pi$ \\
\hline 3 & $97-89$ & 98 & 6 & 316 \\
\hline 4 & $100-10$ & 101 & 4 & 211 \\
\hline 5 & 100.105 & 104 & 2 & 105 \\
\hline & Totd & & 19 & 10000 \\
\hline
\end{tabular}

Data yang disajikan pada tabel di atas memperlihatkan sebaran skor disiplin yang terbagi dalam lima kelompok. Berdasarkan data pada tabel di atas, dapat digambarkan penyebaran skor disiplin dalam bentuk histogram frekuensi yang diperlihatkan pada gambar berikut.

\section{Motivasi}

$$
\text { Data variabel motivasi }
$$

diperoleh berdasarkan hasil pengisian kuesioner yang terdiri atas 50 butir dengan rentang skor teoretis antara 50 sampai 250. Berdasarkan hasil analisis data diketahui skor minimum 134, skor maksimum 158, rentang skor 24 , skor rata-rata 146,37 , median 145, modus 140, standar deviasi 6,70, dan varians 44,91. Distribusi frekuensi skor motivasi dari 19 responden diperlihatkan dalam tabel berikut.

Tabel 4 : Distribusi Frekuensi Skor Motivasi

\begin{tabular}{|c|c|c|c|c|}
\hline No & |riterval & Tok Tenzah & Frecheris Atsodt & Frehere Red \\
\hline 1 & $134-138$ & 130 & 2 & 105 \\
\hline 2 & $138-143$ & 141 & 4 & 21.1 \\
\hline 3 & $144-148$ & 148 & b & 316 \\
\hline 4 & $149-153$ & 151 & 4 & 21,1 \\
\hline 5 & $154-158$ & 156 & 3 & 158 \\
\hline & Todd & & 19 & 10000 \\
\hline
\end{tabular}

Data yang disajikan pada tabel di atas memperlihatkan sebaran skor motivasi yang terbagi dalam lima kelompok. Berdasarkan data pada tabel di atas, dapat digambarkan penyebaran skor motivasi dalam bentuk histogram frekuensi yang diperlihatkan pada gambar berikut.

\section{PENGUJIAN HIPOTESIS}

Pengujian hipotesis statistik diujikan dengan tujuan untuk mengetahui apakah hipotesis nol (Ho) yang diajukan atau diterima pada taraf kepercayaan tertentu. Selanjutnya dilakukan analisis regresi dan korelasi sederhana, regresi dan korelasi ganda, karena hasil penelitian ini ingin mengetahui seberapa besar hubungan yang terjadi antara kedua variabel bebas dan satu variabel terikat.

Pengujian hipotesis statistik pertama, kedua dilakukan dengan uji t. hasil pengujian hipotesis dijelaskan sebagai berikut.

1. Hubungan Hasil latihan beladiri karate dan Disiplin

Hipotesis pertama yang diajukan dalam penelitian ini adalah "terdapat hubungan hasil latihan beladiri karate dengan Disiplin. Dengan demikian diduga semakin tinggi disiplin semakin tinggi hasil latihan beladiri karate. Sebaliknya makin rendah disiplin maka akan rendah hasil latihan beladiri karate.

Analisis regresi linier sederhana antara hasil latihan beladiri karate dengan disiplin, menghasilkan arah koefisien regresi "b" sebesar 0,553 dan konstanta "a" sebesar 3,02 dengan demikian bentuk hubungan variabel Keterampilan hasil latihan beladiri karate dengan disiplin digambarkan oleh persamaan regresi yaitu $\hat{Y}=3,02+0,553$. untuk mengetahui derajat keberartian persamaan regresi sederhana tersebut, dilakukan uji t. Berdasarkan hasil uji $\mathrm{t}$ didapatkan hasil thitung $=2,86$ dan ttabel $=1,74$. Karena nilai thitung $>$ ttabel, maka sehingga persamaan $\hat{Y}=3,02+0,553$ $\mathrm{X} 1$ signifikan

Hubungan disiplin dan hasil latihan beladiri karate dinyatakan dengan nilai koefisien korelasi (r). Berdasarkan hasil perhitungan diperoleh koefisien korelasi antara Y dengan X1 sebesar 0,570, Berdasarkan koefisien korelasi tersebut dapat dicari nilai koefisien determinasi dengan mengkuadratkan nilai korelasi, sehingga diperoleh skor sebesar 32,45\%. Ini berarti disiplin memberikan sumbangan (kontribusi) sebesar 32,45\% terhadap hasil latihan beladiri karate $(\mathrm{Y})$ melalui regresi diperoleh $\hat{Y}=3,02+0,553$. 
2. Hubungan Hasil Latihan Beladiri Karate dan Motivasi

Hipotesis Kedua yang diajukan dalam penelitian ini adalah, "terdapat hubungan hasil latihan beladiri karate dengan motivasi. Dengan demikian diduga semakin tinggi motivasi semakin tinggi hasil latihan beladiri karate. Sebaliknya makin rendah motivasi akan semakin rendah hasil latihan bela diri karate.

Analisis regresi linier sederhana latihan beladiri karate dengan motivasi, menghasilkan arah koefisien regresi " $b$ " sebesar 0,338 dan konstanta "a" sebesar 7,69 dengan demikian bentuk hubungan variabel keterampilan hasil latihan beladiri karate dengan motivasi digambarkan oleh persamaan regresi yaitu $\hat{Y}=7,69+0,338$ $\mathrm{X} 2$ untuk mengetahui derajat keberartian persamaan regresi sederhana tersebut, dilakukan uji t. Berdasarkan hasil uji $\mathrm{t}$ didapatkan hasil thitung $=3,05$ dan ttabel $=1,74$. Karena nilai thitung $>$ ttabel, maka sehingga persamaan $\hat{Y}=7,69+0,338 X 2$ signifikan.

Hubungan motivasi dan hasil latihan beladiri karate dengan nilai koefisien korelasi (r). Berdasarkan hasil perhitungan diperoleh koefisien korelasi $\mathrm{Y}$ dengan x2 sebesar 0,595.

Berdasarkan Koefisien korelasi tersebut dapat dicari nilai koefisien determinasi Motivasi (X2) terhadap keterampilan hasil latihan beladiri karate (Y) adalah sebesar $\mathrm{r} 2=35,44$, sehingga motivasi memberikan sumbangan kontribusi) sebesar $35,44 \%$. Ini berarti bahwa $35,44 \%$ variasi hasil latihan beladiri karate (Y) dapat dijelaskan oleh variabel motivasi melalui regresi $\mathrm{Y}=7,69+0,338$ $\mathrm{X} 2$.

Sesuai dengan hasil analisis hubungan sederhana tersebut dapat disimpulkan bahwa terdapat hubungan yang signifikan antara motivasi (X2) dengan hasil latihan beladiri karate. Hasil pengujian hipotesis kedua ini memberikan informasi yang berharga bahwa hasil latihan beladiri karate sangat ditentukan oleh motivasi.
3. Hubungan Disiplin (X1) dan Motivasi (X2) dengan Hasil latihan beladiri karate $(\mathrm{Y})$

Hipotesis yang diajukan dalam penelitian ini adalah terdapat hubungan hasil latihan beladiri karate dengan disiplin, dan motivasi. digambarkan oleh persamaan regresi yaitu $\hat{\mathrm{Y}}=-13,16+0,361 \mathrm{X} 1+$ $0,239 \times 2$. untuk mengetahui derajat keberartian persamaan regresi ganda tersebut, dilakukan uji r. Berdasarkan hasil perhitungan diperoleh sebesar 0,462. Berdasarkan koefisien korelasi (ry12) tersebut di atas diperoleh koefisien determinasi 0,680 . Hal ini berarti bahwa $68,00 \%$ variansi Hasil latihan bela diri karate dapat dijelaskan oleh variansi disiplin dan motivasi secara bersama-sama.

Untuk menguji keberartian regresi jamak digunakan uji Fhitung. Berdasarkan Hasil perhitungan diperoleh Fhitung sebesar 6,88 sedangkan berdasarkan Daftar Distribusi $\mathrm{F}$ dengan $\mathrm{dk}$ pembilang $2 \mathrm{dan} \mathrm{dk}$ penyebut 16 pada taraf nyata $=0,05$ diperoleh Ftabel sebesar 3,63. Dengan demikian nilai Fhitung lebih besar dari Ftabel; ini menunjukkan bahwa Fhitung signifikan, karena itu persamaan garis regresi yang diperoleh berarti. Analisis korelasi jamak antara $\mathrm{X} 1$ dan $\mathrm{X} 2$ dengan Y menghasilkan koefisien korelasi jamak (R2y.12) sebesar 0,462. Hal ini menunjukan bahwa Fhitung signifikan dan oleh karenanya, koefisien korelasi jamak sebesar 0,462 adalah sangat signifikan.

Kesimpulannya ialah terdapat hubungan positif yang signifikan disiplin dan Motivasi secara bersama-sama dengan hasil latihan bela diri karate. Artinya semakin baik disiplin dan motivasi semakin tinggi pula hasil latihan beladiri karate.

\section{PEMBAHASAN HASIL PENELITIAN}

Hasil analisis korelasional menunjukkan bahwa variabel baik secara sendiri-sendiri maupun secara bersamasama, disiplin dan motivasi, memiliki hubungan yang berate dengan hasil latihan beladiri karate.

Hubungan yang berarti tersebut memiliki arti bahwa disiplin dan motivasi seiring dengan hasil latihan beladiri karate. 
Dengan kata lain peningkatan disiplin dan motivasi, diikuti dengan meningkatnya hasil latihan beladiri karate. Hubungan yang demikian berarti juga bahwa hasil latihan beladiri karate dapat ditelusuri, dijelaskan, atau bahkan diramalkan dari disiplin dan motivasi.

Berdasarkan hasil pengujian hipotesis, ternyata ketiga hipotesis alternatif yang diajukan secara signifikan dapat diterima. Uraian masing- masing penerimaan ketiga hipotesis yang dimaksud dapat dijelaskan sebagai berikut:

1. Pengujian hipotesis pertama menyimpulkan bahwa terdapat hubungan positif yang signifikan disiplin dengan hasil latihan beladiri karate yang ditunjukkan oleh pola hubungan kedua variabel ini dinyatakan oleh persamaan regresi $\mathrm{Y}^{\wedge}=3,02+$ 0,553X1. Persamaan ini memberikaninformasi bahwa setiap perubahan satu tingkat disiplin akan dapat mengakibatkan terjadinya perubahan pada hasil latihan beladiri karate sebesar 0,553 pada konstanta 3,02 .

Hasil analisis korelasi sederhana disiplin dengan hasil latihan beladiri karate diperoleh nilai koefisien korelasi ry1 sebesar 0,570. Nilai ini memberikan pengertian bahwa keterkaitan disiplin dengan hasil latihan beladiri karate adalah signifikan atau positif, artinya makin tinggi disiplin akan diikuti dengan naiknya hasil latihan beladiri karate.

Hasil pengkuadratan nilai koefisien korelasi sederhananya adalah sebesar 0,3245 . Secara statistik nilai ini memberikan pengertian bahwa $32,45 \%$ variasi hasil latihan beladiri karate ditentukan/dijelaskan oleh disiplin dengan pola hubungan fungsionalnya seperti ditunjukkan oleh persamaan regresi tersebut di atas.

2. Pengujian hipotesis kedua menyimpulkan bahwa terdapat hubungan positif yang signifikan motivasi dengan hasil latihan beladiri karate yang ditunjukkan oleh pola hubungan kedua variabel ini dinyatakan oleh persamaan regresi $\mathrm{Y}^{\wedge}=7,69+$ 0,338 X2.

Persamaan ini memberikan informasi bahwa setiap perubahan satu tingkat motivasi akan dapat mengakibatkan terjadinya perubahan pada hasil latihan beladiri karatecsebesar 0,338 pada konstanta 7,69 .

Hasil analisis korelasi sederhana koordinasi motivasi dengan hasil latihan beladiri karate diperoleh nilai koefisien korelasi ry2 sebesar 0,674. Nilai ini memberikan pengertian bahwa keterkaitan motivasi dengan hasil latihan beladiri karate adalah signifikan atau positif, artinya makin tinggi motivasi akan diikuti dengan naiknya hasil latihan beladiri karate

Hasil pengkuadratan nilai koefisien korelasi sederhananya adalah sebesar 0,3544 . Secara statistik nilai ini memberikan pengertian bahwa $35,44 \%$ variasi hasil latihan beladiri karate ditentukan/dijelaskan oleh motivasi dengan pola hubungan fungsionalnya seperti ditunjukkan oleh persamaan regresi tersebut di atas.

3. Pengujian hipotesis menyimpulkan terdapat hubungan yang positif dan signifikan disiplin dan motivasi secara bersama-sama dengan hasil latihan beladiri karate yang ditunjukkan oleh nilai Fhitung sebesar 6,80. Nilai ini jauh lebih besar dari pada nilai Ftabel pada taraf signifikansi alpa 0,05 yaitu 3,63 , atau $\mathrm{F}=6,80>\mathrm{F} 0,05(3 ; 16)=3,63$. Pola hubungan antara ketiga variabel yang dinyatakan oleh persamaan regresi ganda $\mathrm{Y}^{\wedge}=-13,16+0,361 \mathrm{X} 1+$ $0,239 X 2$. Persamaan ini memberikan informasi bahwa setiap perubahan satu unit skor disiplin dan motivasi akan mengakibatkan terjadinya perubahan hasil latihan beladiri karate.

Hasil analisis korelasi ganda disiplin dan motivasi diperoleh nilai koefisien korelasi ganda sebesar Ry.12 sebesar 0,462 . Nilai ini menunjukkan bahwa keterkaitan disiplin dan motivasi secara bersama- sama dengan hasil latihan beladiri karate adalah baik. Dengan demikian berarti makin naiknya disiplin 
dan motivasi maka diikuti dengan tingginya hasil latihan beladiri karate.

Besarnya sumbangan atau kontribusi variabel disiplin dan motivasi terhadap hasil latihan beladiri karate bersama-sama dapat diketahui melalui nilai koefisien determinasi R2y123 sebesar 0,680. Hasil analisis tersebut menunjukkan bahwa $68,0 \%$ variasi hasil latihan beladiri karate ditentukan/dijelaskan oleh disiplin dan motivasi secara bersama-sama dengan pola hubungan fungsionalnya seperti ditunjukkan oleh persamaan regresi tersebut di atas. Sedangkan 32,0\% ditentukan oleh variabel lainnya.

\section{KESIMPULAN}

Berdasarkan data yang diperoleh, hasil pengujian hipotesis dan pembahasan hasil penelitian dapat disimpulkan bahwa:

1. Terdapat hubungan yang berarti antara disiplin (X1) dengan hasil latihan beladiri karate $(\mathrm{Y})$.

2. Terdapat hubungan yang berarti antara motivasi (X2) dengan hasil latihan beladiri karate $(\mathrm{Y})$.

3. Terdapat hubungan yang berarti antara disiplin (X1) dan motivasi (X2) secara bersama sama dengan hasil latihan beladiri karate (Y).

\section{SARAN}

Berdasarkan temuan hasil penelitian ini khususnya untuk keterampilan hasil latihan beladiri karate, maka beberapa saran dapat diajukan sebagai berikut:

1. Disiplin sebagai salah satu variabel penting yang menunjang mengembangkan hasil latihan beladiri karate dan dengan meningkatkan disiplin anak, maka anak akan berlatih secara teratur sehingga hasil latihan beladiri karatenya pun akan baik.

2. Hasil latihan beladiri karate salah satunya ditentukan oleh Motivasi. Pemberian motivasi baik oleh orang tua maupun pelatih akan membangkitkan keinginan anak untuk terus berlatih bela diri karate.

3. Penelitian ini dapat ditindaklanjuti dengan penelitian lain, yang mengkaji variabel-variabel penting penunjang hasil latihan beladiri karate dengan melibatkan variabel dalam jumlah yang lebih banyak dan lebih kompleks, yang secara teoritik maupun empiris menunjang hasil latihan beladiri karate.

\section{DAFTAR PUSTAKA}

Hurlock, Elizabeth B. Perkembangan Anak. Jakarta: Cendekia, 1978.

Ilham,H. Subroto. Dasar-Dasar Karate. Solo: AIC Offset, 1996.

JB Sujoto. Teknik Oyama Karate. Jakarta: PT Elex Media Komputindo, 1996. Nana, Sudjana. Metode Statistik. Bandung: Tarsito, 1992.

Patric, M. Hickey. Karate Technique \& Tactics.USA, Perigee Books. Jakarta: Ghalla Indonesia, 1995.

Paul, Perry. Bebas Cedera karate. Jakarta: Ghalla Indonesia, 1994. Rose, Mini. Disiplin Pada Anak. Jakarta: Erlangga, 2011.

Singgih, Gunarsa D. Psikologi Olahraga. Jakarta: Gunung Mulia. 1989.

Soedibyo, Soebroto. Psikologi Olahraga. Jakarta: Unit Percetakan UNJ, 2002.

Simanjuntak, G.Viktor. Teknik Dasar Karate. Ciputat: CerdasJaya 2004.

Suharsimi, Arikunto. Prosedur Penelitian Suatu Pendekatan Praktek. Jakarta: PT. Rineka Cipta, 2006.

Tangkudung, James. Kepelatihan Olahraga, Pembinaan Prestasi Olahraga II. Jakarta: Cerdas Jaya, 2010.

Winarno, Psikologi Perkembangan Anak. Jakarta: Platinum, Oktober 2012. 